1610

70 巻 694 号 (2004-6)

\author{
サステイナビリティを考慮した \\ 水素エネルギーシステムのライフサイクル評価* \\ (自動車燃料としての導入可能性について)
}

大 竹毅*1, 長 島 昭*2

\title{
Life-Cycle Assessment of Hydrogen Energy System in Sustainability Perspective (Adaptability to the Vehicle Fuel)
}

Tsuyoshi OTAKE and Akira NAGASHIMA*3

\author{
${ }^{*}$ Faculty of Science and Technology, Keio University, \\ 3-14-1 Hiyoshi, Kouhoku-ku, Yokohama-shi, Kanagawa, 223-8522 Japan
}

\begin{abstract}
Hydrogen Energy is expected to be one of the keys to sustainable development. But this expectation comes from the idea focusing only on the particular phase of interest, such as production or use phase of hydrogen energy. The sustainability of the hydrogen energy will be clear by considering the Life-Cycle of the hydrogen energy system. In the present study, using the method of the Life-Cycle Assessment, the hydrogen energy system was analyzed considering the construction of infrastructures. The assessment aspects are Energy, $\mathrm{CO}_{2}$, Cost and Land-Use. The hydrogen energy was also examined the adaptability to the vehicle fuel. The hydrogen energy which improves environmental impacts and costs in the acceptable range was selected. As a result, hydrogen energy for the vehicle fuel has to be produced by natural-gas reforming. And if the carbon tax is introduced, water electrolysis using the nuclear power is also possible.
\end{abstract}

Key Words: Alternative Energy, Automobile, Fuel Cell, Hydrogen Energy, Sustainability, LCA, Energy, $\mathrm{CO}_{2}$

\section{1.}

石油をはじめとしたエネルギ一資源の枯渇問題や， 地球温暖化問題から, 水素エネルギ一が注目されてい る. この水素エネルギ一は, 自然エネルギ一をはじめ 様々な-次エネルギ一源からの生産が可能であると同 時に, 002 の排出を伴うことなく高効率な利用が可 能であることから, サステイナビリティを有する究極 のクリーンエネルギーとして期待されている. そして, このような背景のもとに, 水素エネルギ一を利用する ための機器開発が各方面で進められている.

水素エネルギーの生産や利用といつた特定の段階 だけに着目すれば, 水素エネルギ一の価值は容易に示 すことが出来る. しかし, 水素エネルギ一は一次エネ ルギーであり, 化石燃料を用いた現状のエネルギーシ ステムとは環境負荷構造が異なる. それゆえ限定され

\footnotetext{
* 原稿受付 2003 年 4 月 1 日.

*1 慶應義塾大学大学院理工学研究科(亚223-8522 横浜市港北 区日吉 3-14-1)

*2 正員, 慶應義塾大学理工学部.

E-mail : nagasima@sd.keio.ac.jp
}

た段階にのみ着目した議論では, 水素エネルギ一特有 の潜在的な環境負荷を見出すことが出来ない. そこで, 水素エネルギ一の生産, 貯蔵, 輸送, 供給を含むエネ ルギーシステム全体に着目する必要がある.さらには, 水素エネルギーシステムは現在ない新たなエネルギー システムであることから，それを支えるインフラスト ラクチャーの構築がもたらす影響をも考慮する必要が ある. そして, このような視点から, 水素エネルギ一 を導入する価値を検討しなくてはならない.

そこで本研究では，水素エネルギーシステムのイ ンフラを構成する各機器の建設, 運用, 保守を含めた Life-Cycle Assessment（LCA）を実施した.この時， 水素エネルギ一の利用先としては, 現実のものとなり つつる燃料電池自動車を対象とした. 一方, 現状の ガソリン自動車用の燃料が持つエネルギーシステム, すなわち，ガソリン（石油）システムを対象とした LCA も併せて行った. そして, 両者の結果を比較す ることで，水素エネルギ一が持つ自動車用燃料として の導入可能性を検討した. この時，水素エネルギ一は 経済性に問題があることから, ガソリンとのコスト格 
差是正を目的とした何らかの課税が必要であると指摘 し, 炭素税導入の効果も検討した.

\section{2. 対象とした水秦エネルギーシステム}

本研究で対象とした水素エネルギーシステムのライ フサイクル概念図を図1に示す，ただし，生産にあた って用いる 次エネルギ一源は, 自然エネルギ一（水 力, 風力, 太陽光）之原子力, さらには天然ガス, 石 炭とした. そして, これらを用いて発電した電力によ って, 水を電気分解することで水素エネルギ一を生産 するケースと, 天然ガス，石炭については，改質およ びガス化によって生産するケースも考えた．また，海 外における生産ケースと, 国内における生産ケースに ついて考えた.

\section{3. 対象とした評価項目と算出摡念}

「エネルギー面」の評価指標として, Life-Cycle ENERGY（LCE）を「環境面」の評価指標として, Life-Cycle $\mathrm{OO} 2$ ( LCOO2) および Land-Use （LandUs）を，「経済面」の評価指標として, LifeCyde COST (LCOOST) を対象とした.

そこで以下において，これらの評価指標に関する原 単位データの算出方法を示す.

\section{3 - 1 Life-Cycle ENERGY（LCE）}

式 (1) のように, 水素エネルギーシステムを構成 する各インフラ設備の建設, 運用, 保守段階における エネルギー消費量（本稿では、化石燃料消費量を意味 する）を求め，これを当該設備におけるライフタイム （律 25 年とした）での水素エネルギー取扱量で除 す. そして, 各インフラ設備に関する原単位データを, 全インフラ設備にわたって足し上げることで, 水素エ ネルギーシステムを対象とした LCE 算出した.

$$
E_{L . C}=\sum_{i} E_{L . C}(i)=E_{C}(i)+E_{U}(i)+E_{M}(i)
$$

$E_{L C}$ : 水素エネルギーシステム全体でのライフサイク ルエネルギー原単位 $\left(\mathrm{kJ} / \mathrm{kJ}-\mathrm{H}_{2}\right)$

$E_{L C}(\boldsymbol{i})$ : インフラ設備iのライフサイクルエネルギー原 単位 $\left(\mathrm{kJ} / \mathrm{kJ}-\mathrm{H}_{2}\right)$

$E_{C}(i)$ : インフラ設備 $i$ の建設段階におけるエネルギー 消費原単位 $\left(\mathrm{kJJ} / \mathrm{kJ}-\mathrm{H}_{2}\right)$

$E_{U}(i)$ : インフラ設備 $i$ の運用段階におけるエネルギー 消費原単位 $\left(\mathrm{kJ} / \mathrm{kJ}-\mathrm{H}_{2}\right)$

$E_{M}(i)$ : インフラ設備 $i$ で保守段階におけるエネルギ一 消費原単位 $\left(\mathrm{kJ} / \mathrm{kJ}-\mathrm{H}_{2}\right)$

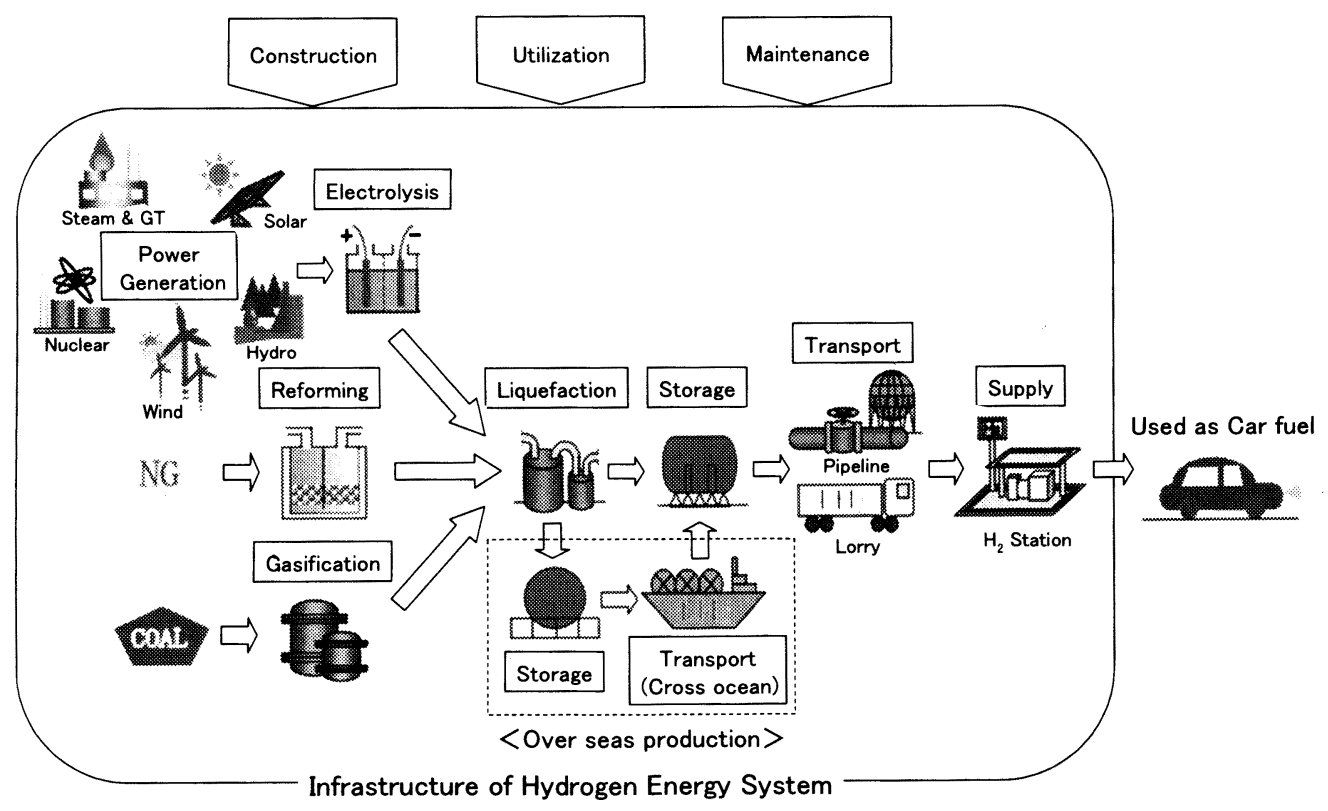

Fig.1 Life-Cycle Image of the Hydrogen Energy System 
続いて, 各インフラ設備の建設, 運用, 保守段階に おけるエネルギ一消費量の算出方法について示す.

（1）建設段階について

建設段階は「素材製造工程」と「プラント製造工 程」から成り立つものとし，「素材製造工程」での工 ネルギー消費量は, 各素材の重量にその素材のエネル ギ一消費原単位を乗じたものを, 各インフラ設備を構 成する全ての素材について足しあわせることで算出し た. また「『プラント製造工程』でのエネルギー消費 量は『素材製造工程』でのエネルギー消費量の $20 \%$ である」とした，そして，両者の和を当該設備のライ フタイムにおける水素エネルギ一取扱量で除すことに より, 式（2）のように算出した. ただし，各設備の 構成素材等に関するデー夕は文献叫仍らら引用した.

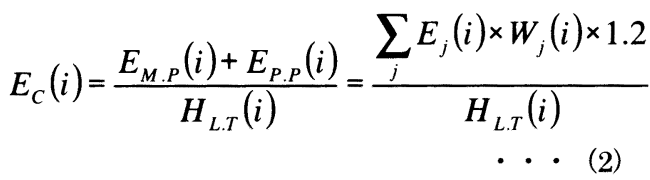

$E_{M . P}(\boldsymbol{l})$ : インフラ設備 $i$ の幸材製造工程でのエネルギー 消費量 $(\mathrm{kJ})$

$E_{P . P}(i)$ : インフラ設備 $i$ のプラント製造工程でのエネル ギー消費量 (kJ)

$H_{L . T}(\boldsymbol{l})$ : インフラ設備 $i$ のライフタイムにおける水素エ ネルギー取扱量 $\left(\mathrm{kJ}-\mathrm{H}_{2} \mathrm{~L} \mathrm{LT}\right)$

$E_{j}($ l) : インフラ設備 $i$ を構成する素材 $j$ のエネルギ一消 費原単位 $(\mathrm{k} / \mathrm{kg})$

$W_{j}(i)$ : インフラ設備 $i$ を構成する素材 $j$ の重量 $(\mathrm{kg})$

（2）運用段階について

運用段階でのエネルギ一消費量は各設備のエネルギ 一効率から算出し, 投入するエネルギ一は水素エネル ギ一の形で供給することとした. この時, 水素エネル ギーシステムを構成するインフラ設備群の内, 上流か

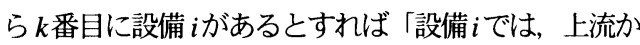
ら $(k-1)$ 番目の設備まで経由した水素エネルギ一を 使用する」と考え, 各設備に投入する水素エネルギ一 のライフサイクルをも考慮した.

$$
E_{U}(i)=\left(\frac{1}{\eta_{i}}-1\right) \times E_{L . C}(k-1) \ldots(3)
$$

$n_{i}$ : インフラ設備 $i$ の運用時におけるエネルギ一効率
$E_{L C C}(k-1)$ : 上流から $(k-1)$ 番目の設備までを対象と した時のライフサイクルエネルギ一原単位 $\left(\mathrm{k} J / k J-H_{2}\right)$

（3）保守段階について

保守段階で消費するエネルギ一は，「建設段階で消 費するエネルギ一の $5 \%$ が，毎年，消費される」と仮 定して算出した.

$$
E_{M}(i)=E_{C}(i) \times 0.05 \times \operatorname{L.T}(i) \quad \cdots(4)
$$

\section{$L . T(i)$ : インフラ設備 $i$ の耐用年数（年）}

以上のような仮定とは別に, 各インフラ設備の内, 水素エネルギーシステムの起点にあたる発電設備や天 然ガス改質設備，石炭ガス化設備に関しては，LCE 解析が既に実施されているため, その結果的を用い た. また, パイプライン, 水素スタンドに関しては, 現行の都市ガスパイプライン，ガソリンスタンドと全 く同様であると考え, 既に実施されている LCE 解析 の結果河を引用した.

インベントリデータを算出する上での計算は，マト リクス上の表を作成して行なった. そこで, 日本国内 で太陽光発電（Sol. P. Generation）を用いて水素工ネ ルギーを生産し，タンクローリーによって輸送する場 合について例示する. ただし，運用段階が 3 つに分か れているのは，各設備の運用に際し投入する水素工ネ ルギーのライフサイクルも考慮していることから, 投 入する水素エネルギ一のライフサイクルの内, どの段 階に起因するものであるかを明らかにするためである. また、太陽光発電の運用段階でのエネルギ一消費が 0 となっているのは、前述したように、LCE の対象を

\begin{tabular}{|c|c|c|c|c|c|c|c|}
\hline \multirow{3}{*}{ Facility Stage } & \multirow{3}{*}{$\begin{array}{l}\text { Const: } \\
\text { ruction }\end{array}$} & \multicolumn{3}{|c|}{ Utilization } & \multirow{3}{*}{$\begin{array}{c}\text { Main } \\
\text { tenamese }\end{array}$} & \multirow{3}{*}{ Total } & \multirow{3}{*}{$\begin{array}{l}\text { Effi- } \\
\text { ciency }\end{array}$} \\
\hline & & \multicolumn{3}{|c|}{ originated in $\ldots$} & & & \\
\hline & & $\begin{array}{l}\text { Const- } \\
\text { ruction }\end{array}$ & $\begin{array}{l}\text { Utili. } \\
\text { zation }\end{array}$ & $\begin{array}{c}\text { Main } \\
\text { tenamce }\end{array}$ & & & \\
\hline Sol. P. Generation & $1.11 \mathrm{E}+00$ & 0) & 0 & (0) & $2.76 \mathrm{E} \cdot 01$ & $1.38 \mathrm{E}+00$ & - \\
\hline Water lilectrolysis & $2.77 \mathrm{E} \cdot 07$ & \multicolumn{3}{|c|}{ includecl in generation } & $3.46 \mathrm{E} \cdot 07$ & $6.24 \mathrm{E} \cdot 07$ & - \\
\hline liquefaction & $2.31 \mathrm{E} \cdot 0.3$ & $2.76 \mathrm{E} \cdot(0)$ & 0) & $6.90 \mathrm{E} \cdot 02$ & $2.896-0.3$ & $3.51 \mathrm{E} \cdot 01$ & 0.8 \\
\hline Storage & $1.59 \mathrm{E} \cdot 0.3$ & $2.83 \mathrm{E} \cdot 02$ & (1) & \begin{tabular}{|l|}
$7.10 \mathrm{E}-0.3$ \\
\end{tabular} & \begin{tabular}{|l|}
$1.99 \mathrm{E} \cdot 0.3$ \\
\end{tabular} & $3.89 \mathrm{E} \cdot 02$ & 0.98 \\
\hline Lorry (Transport) & $9.59 \mathrm{E}-04$ & $7.44 \mathrm{E}-02$ & 0) & $1.88 \mathrm{E} \cdot 02$ & $3.36 \mathrm{KE} \cdot 04$ & $9.45 \mathrm{E} \cdot 02$ & 0.95 \\
\hline $\mathrm{II}_{2}$ Station (Supply) & $1.52 \mathrm{E} \cdot 03$ & o) & 0) & () & $1.07 \mathrm{E}-(04$ & $1.63 \mathrm{E} \cdot 0.3$ & - \\
\hline Total & 1.1 .4 .00 & 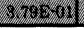 & (2) & 9.4950 .01 & $2812=0$. & $1,827+00$ & \\
\hline
\end{tabular}
化石燃料消費量としているためである.

Table1 Example of calculation form of Inventory data 
次に, 表 1 に示す薄灰色の部分を積み上げることで, ライフサイクルステージ別の LCE 分析を実施した. 日本国内で水素エネルギーを生産する場合について, その結果を図 2 に示す．なお、天然ガス改質設備の総 合効率は、文献を用いて $53 \%$ 之計算した。

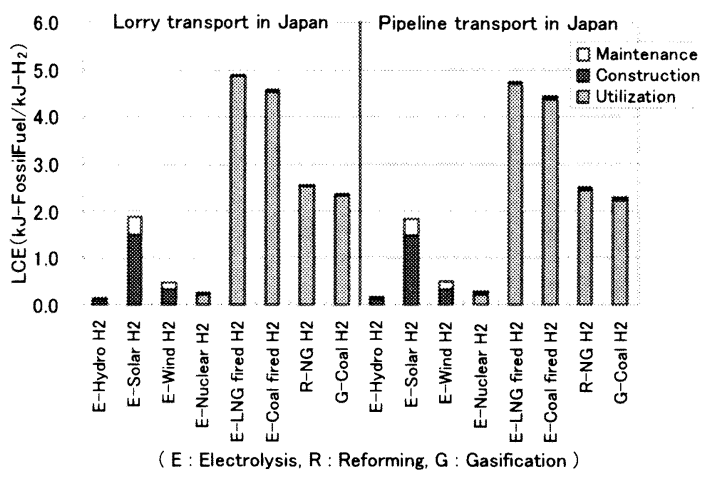

Fig2 Life-Cycle Energy of the Hydrogen Energy produoed in Japan

ガソリンの場合については，既に実施されている LCE 解析の結果相引用することで, 水素エネルギー の場合と同様に「石油（ガソリン）システム全体での ライフサイクルエネルギー原単位」を算出した.

\section{$3 \cdot 2$ Life-Cycle $\mathrm{CO} 2$ (LCCO2)}

LCE の場合と全く同様の仮定，流れで算出を行な った. すなわち, エネルギ一消費に関する原単位では なく, 002 排出原単位を用いて算出した. そこで, 国内で水素エネルギーを生産する場合のライフサイク ルステーシ別 LOOO2 分析について, 結果のみを図 3 に示す.

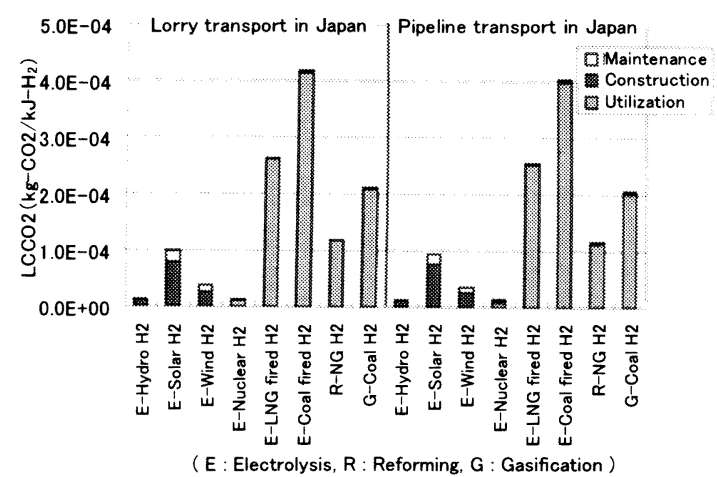

Fig. 3 Life-Cycle $\mathrm{OO} 2$ of the Hydrogen Energy produced in Japan
ガソリンの場合については, 石油 (ガソリン) シス テムを構成する各インフラ設備の素材構成デー夕目を もとに, 水素エネルギ一の場合と同様に「石油（ガソ リン）システム全体でのライフサイクル $\mathrm{OO2}$ 排出原 単位」を算出した.

\section{3 - 3 Life-Cycle COST (LCCOST)}

式（5）のように, 水素エネルギ一の生産コスト, 液化貯蔵コスト, 輸送コストを足し合わせることで, LCOOST を算出した.

$$
P_{L . C}=P_{P}+P_{L \& S}+P_{T} \quad \cdots(5)
$$

$P_{L . C}:$ ライフサイクルコスト $\left(\right.$ 円 $\left./ \mathrm{kJ}-\mathrm{H}_{2}\right)$

$P_{P}:$ 生産コスト $\left(\right.$ 円 $\left./ \mathrm{kJ}-\mathrm{H}_{2}\right)$

$P_{\text {LeS }}$ : 液化貯蔵コス卜 $\left(\right.$ 円 $\left./ \mathrm{kJ}-\mathrm{H}_{2}\right)$

$P_{T}$ : 輸送コスト $\left(\right.$ 円 $\left./ \mathrm{kJ}-\mathrm{H}_{2}\right)$

式（5）中の液化貯蔵コストおよび輸送コストに 関しては, どのような 次エネルギーから水素エネ ルギーを生産した場合でも 定となる. そこでこれ らのコストに関しては, 文献[4[5]で既に算出されて いる值を引用した.

·方，生産コストに関しては，生産方法および生 産に用いる 次エネルギーによって異なる. そこで, 生産コストを固定費と変動費に分け，変動費部分は 次エネルギーコストに応じた感度分析が実行でき るような形にした. この時, 生産設備の運転条件や 必要経費等は文献[4|[5]に従った. また, 定常項であ る固定費についても文献 値を引用した. 式（6）に, 水電解によって水素工 ネルギーを生産する場合を例とした生産コストの算 出方法を示す. そして, 図 4 に電力コストと生産 コストの関倸を示す。

$$
P_{P}=P_{P}-f i x+P_{E . P} \times E_{W . E} \quad \cdots(6)
$$

$P_{P_{-}} f i x$ : 生産コストの固定費 (円 $\left./ \mathrm{kJ}-\mathrm{H}_{2}\right)$

$P_{E . P}:$ 電力コスト $($ 円 $/ \mathrm{kWh})$

$E_{W . E}$ : 水電解に必要なエネルギ一量 $\left(\mathrm{kJ} / \mathrm{kJ} \mathrm{H}_{2}\right)$ 


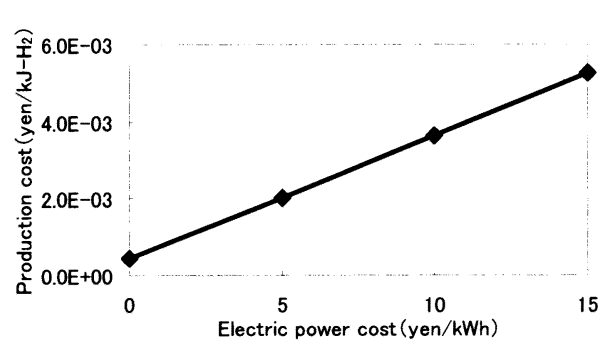

Fig.4 Relation between electric power cost and production cost of Hydrogen Energy

次に, 日本国内で水素エネルギーを生産する場合 のLCCOST 分析の結果を図 5 に示す. ただし, 国 内において水素エネルギーを生産する際の電力コス 卜は文献[7]18わら, 天然ガスおよび石炭のコスト

(CIF コスト) は日本エネルギー経済研究所の統計 情報（2002 年 6 月期） 99 から引用した.

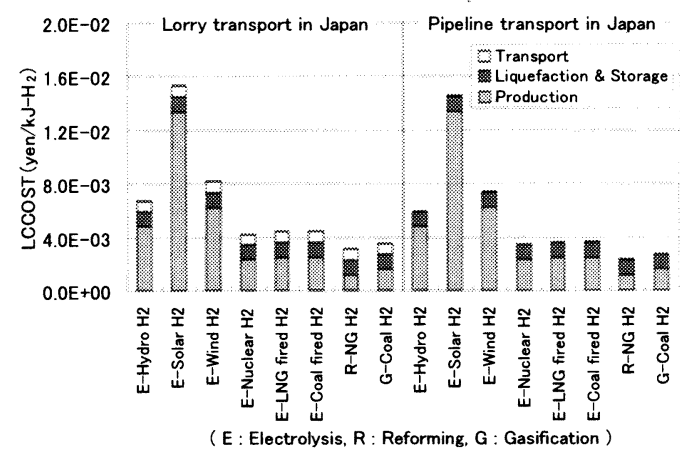

Fig.5 Life-Cycle Cost of the Hydrogen Energy produced in Japan

一方, ガソリンの販売価格の内訳[101は，表 2 のよ うになっており, 約 6 割が政策的に操作可能な税 金にあたる. そこで, 原価である 43.4 円/Lをガソ リンの LCCOST として考えることとした.

Table2 Details of the Gasoline sales price

\begin{tabular}{|c|c|c|}
\hline \multicolumn{3}{|c|}{ (Unit : yen/L ) } \\
\hline \multirow{4}{*}{ Cost } & Crude CIF price & 16.4 \\
\hline & Purification & 3 \\
\hline & Management & 6 \\
\hline & Distribution & 18 \\
\hline & Gasoline cost & 43.4 \\
\hline \multirow{4}{*}{ Tax } & Import tariff & 0.215 \\
\hline & Oil tax & 2.04 \\
\hline & Gasoline tax & 53.8 \\
\hline & Sales price & 99.455 \\
\hline
\end{tabular}

\section{$3 \cdot 4$ Land-Use (LandUse)}

我が国のような国土面積の狭い国では，水素エネ ルギーの生産にあたって「いかに国土面積を有効利 用できるか?」といった指標もサステイナビリティ の観点から重要である. なぜなら, 水素エネルギー の生産に自然エネルギーを利用すれば，非常にクリ ーンではあるが, 一方で, 広大な国土が必要となる からである. そこで, 式 (7) のように「単位量の 水素エネルギーを生産する際に, そのインフラ設備 が占有する土地面積（LandUse）」を算出し, 比較 した. ただし, 発電設備に関する土地面積デー夕は 文献[11] [13]，その他の設備に関する土地面積デー夕 は文献5114から引用した。

$$
S_{P . P}=\frac{S(P)}{H_{Y}(P)}
$$

$S_{P . P}$ : 単位量の水素エネルギ一生産にあたって占有 する土地面積 $\left(\mathrm{m}^{2} / \mathrm{kJ}-\mathrm{H}_{2}\right)$

$S(P)$ : 水素生産設備が占有する土地面積 $\left(\mathrm{m}^{2}\right)$ $H_{Y}(P)$ : 生産設備の年間水素取扱量 $\left(\mathrm{kJ}-\mathrm{H}_{2} / \mathrm{year}\right)$

水素エネルギ一生産に関わる LandUse 分析の結果 を表 3 に示す.

Table3 Land-Use in Hydrogen Energy production

\begin{tabular}{|c|r|r|c|}
\hline & \multicolumn{3}{|c|}{ LandUse $\left(\mathrm{m}^{2} / \mathrm{TJ}-\mathrm{H}_{2}\right)$} \\
\cline { 2 - 4 } & Power plant & $\mathrm{E}$ or R or G plant & Total \\
\hline E-Hydro $\mathrm{H}_{2}$ & $4.2 \mathrm{E}+06$ & $1.9 \mathrm{E}+01$ & $4.2 \mathrm{E}+06$ \\
\hline E-Wind $\mathrm{H}_{2}$ & $3.8 \mathrm{E}+05$ & $1.9 \mathrm{E}+01$ & $3.8 \mathrm{E}+05$ \\
\hline E-Solar $\mathrm{H}_{2}$ & $3.4 \mathrm{E}+05$ & $1.9 \mathrm{E}+01$ & $3.4 \mathrm{E}+05$ \\
\hline E-Nuclear $\mathrm{H}_{2}$ & $6.5 \mathrm{E}+02$ & $1.9 \mathrm{E}+01$ & $6.7 \mathrm{E}+02$ \\
\hline E-LNG fired $\mathrm{H}_{2}$ & $9.4 \mathrm{E}+02$ & $1.9 \mathrm{E}+01$ & $9.6 \mathrm{E}+02$ \\
\hline E-Coal fired $\mathrm{H}_{2}$ & $8.4 \mathrm{E}+02$ & $1.9 \mathrm{E}+01$ & $8.6 \mathrm{E}+02$ \\
\hline \hline R-NG $\mathrm{H}_{2}$ & - & $3.0 \mathrm{E}+01$ & $3.0 \mathrm{E}+01$ \\
\hline G-Coal $\mathrm{H}_{2}$ & - & $1.0 \mathrm{E}+02$ & $1.0 \mathrm{E}+02$ \\
\hline
\end{tabular}

ガソリンの場合は，トーラス製油所[15]の土地面積 データから, 水素エネルギ一の場合と同様に「単位 量のガソリンを生産する際に, そのインフラ設備が 占有する土地面積（LandUse）」を算出した.

\section{4. 柲能举位の設定}

水素エネルギーを用いた燃料電池自動車と, ガソ リン自動車を比較する際の機能単位を「自動車 $1 \mathrm{~km}$ 
走行あたり」に設定した. そして, 第3 章で算出した 各原単位デー夕に単位距離走行でのエネルギ一消費量 を乗じることによって，「自動車 $1 \mathrm{~km}$ 走行あたり」 の LCE, LCOO2, LCOOST, LandUse を算出した. この時, ガソリン自動車の燃料消費率を $0.1 \mathrm{Lkm}$ (10 $\mathrm{km} / \mathrm{L}$ に対応）とした. また, 燃料電池自動車の燃料 消費率は, ガソリン自動車と動力システムのみが異な り, 車両重量や走行抵抗などは全て同じであると仮定 して, 式（8）のように算出した. ただし, 式中の

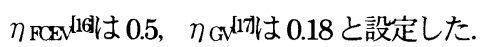

$$
F E_{F C E V}=F E_{G V} \times \frac{\eta_{G V}}{\eta_{F C E V}} \quad \cdots
$$

$F E_{F C E V}$ : 燃料電池自動車の燃料消費率 $\left(\mathrm{kJ}-\mathrm{H}_{2} / \mathrm{km}\right)$ $F E_{G V}$ : ガソリン自動車の燃料消費率（kJ-G/km） $\eta_{F C E V}$ : 燃料電池自動車のエネルギ一効率 $n_{G V}:$ ガソリン自動車のエネルギー効率

\section{5. 水秦エネルギーシステムの环境負荷䅦造}

LCOO2 を例に、水素エネルギーシステムの持つ環 境負荷構造とガソリン (石油) システムとを比較する. ただし, 水素エネルギ一は日本国内で生産し, タンク ローリーによって輸送することとし, 石炭ガス化によ る水素エネルギー $\left(\mathrm{G}-\mathrm{Coal} \mathrm{H}_{2}\right)$, 太陽光発電を用い た水電解による水素エネルギ一 $\left(\mathrm{E}-\mathrm{Solar} \mathrm{H}_{2}\right)$, 風 力発電を用いた水電解による水素エネルギー（EWind $\left.\mathrm{H}_{2}\right)$, 原子力発電を用いた水電解による水素工 ネルギー $\left(\mathrm{E}-\mathrm{Nuclear} \mathrm{H}_{2}\right)$, を例として図に示した.

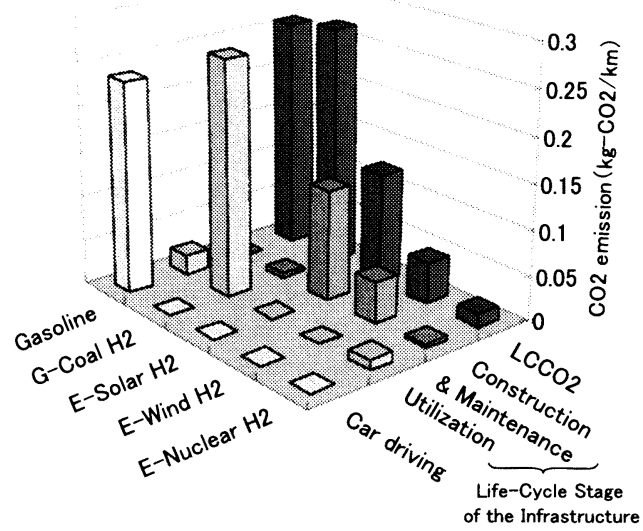

Fig.6 $\mathrm{OO} 2$ emission structure of the Hydrogen Energy System
図6は以下のように解釈できる. つまり, 水素 エネルギーを用いることによって, 自動車走行時の $\mathrm{CO} 2$ 排出を 0 にすることが出来る. しかし, イン フラの運用段階, すなわち, 自動車走行に必要な工 ネルギーを生産し, 輸送して, 我々に供給されるま での段階に着目すると, 石炭ガス化によって生産さ れる水素エネルギーからの $\mathrm{CO} 2$ 排出が非常に大き くなる. さらに, インフラの建設保守段階に着目 すると, 太陽光や風力と言った自然エネルギーを用 いた水素エネルギーからの $\mathrm{CO} 2$ 排出が大きくなる. そして最後に, 各段階の和である LCCO2 に着目す ると, 石炭ガス化によって生産される水素エネルギ 一は, ガソリンよりも $\mathrm{CO} 2$ 排出量が多くなってし まうことがわかる.

以上から，「水素エネルギ一であっても，そのラ イフサイクルを考えると, 現状よりも環境を悪化さ せることがあり得る」と指摘できる．また，「太陽 光を用いた場合にも, $\mathrm{CO} 2$ 排出が 0 になることは なく, ガソリンのたかだか半分にしかならない」と 指摘できる. このことは, 水素エネルギーはクリー ンであることを前提とした議論や機器開発の現場に おいて，見落としがちになる視点である，と考える.

\section{6. 自峌車用然料としての渻入可能性}

第3 章で算出した各項目に対する全ての評価結果を, 表 4 にまとめた. ただし「自動車 $1 \mathrm{~km}$ 走行あたり」 を機能単位とし, 日本国内で水素エネルギ一を生産し た場合について, 石油 (ガソリン) システムの評価結 果を“1”とした場合の相対值として提示している.

Table4 Results of each assessment

\begin{tabular}{|c|c|c|c|c|c|c|}
\hline & & & $\mathrm{LCCO} 2$ & LCE & LandUse & LCCOST \\
\hline \multicolumn{3}{|c|}{ Gasoline (oil) System } & 1 & 1 & 1 & 1 \\
\hline \multicolumn{2}{|c|}{$\mathrm{H}_{2}$ Production } & \multirow{2}{*}{$\begin{array}{c}\text { Transport way } \\
\text { in Janan }\end{array}$} & & & & \\
\hline Area & Process & & & & & \\
\hline \multirow{16}{*}{ Japan } & \multirow{2}{*}{ E-Hydro } & Lorry & 0.1 & 0.04 & \multirow{2}{*}{$4: 96$} & 20 \\
\hline & & Pipeline & 0.1 & 0.1 & & 17. \\
\hline & \multirow{2}{*}{ E-Solar } & Lorry & 0.5 & 0.6 & \multirow{2}{*}{800} & 2.4. \\
\hline & & Pipeline & 0.5 & 0.6 & & 70 \\
\hline & \multirow{2}{*}{ E-Wind } & Lorry & 0.2 & 0.2 & \multirow{2}{*}{10} & 9. \\
\hline & & Pipeline & 0.2 & 0.2 & & 21 \\
\hline & \multirow{2}{*}{ E-Nuclear } & Lorry & 0.1 & 0.1 & \multirow{2}{*}{0.8} & 12 \\
\hline & & Pipeline & 0.1 & 0.1 & & 10 \\
\hline & \multirow{2}{*}{$E$-LNG fired } & Lorry & 1.8 & 1.6 & \multirow{2}{*}{ 1.) } & 13. \\
\hline & & Pipeline & 12 & 1,6 & & 1.1. \\
\hline & \multirow{2}{*}{ E-Coal fired } & Lorry & 20 & 1.6 & \multirow{2}{*}{1.0} & 1.8 \\
\hline & & Pipeline & 2.0 & 1.5 & & 12 \\
\hline & \multirow{2}{*}{$\mathrm{R} \cdot \mathrm{NG}$} & Lorry & 0.6 & 0.8 & \multirow{2}{*}{0.02} & 0.9 \\
\hline & & Pipeline & 0.6 & 0.8 & & 0.7 \\
\hline & \multirow{2}{*}{ G-Coal } & Lorry & 10 & 0.8 & \multirow{2}{*}{0.1} & 1.0 \\
\hline & & Pipeline & 10 & 0.8 & & 0.8 \\
\hline
\end{tabular}

(E: Electrolysis, R: Reforming, G: Gasification) 
サステイナビリティを考える際には，上表の各数值 が示すバランスに着目することが重要である. 特定の 項目だけがガソリンに比べて突出して優れていても, 他の項目が劣っていては, それはサステイナビリティ の観点から歓迎されることではない. たとえ環境性が 優れていても, 経済性が伴わないものは、サステイナ ビリティの観点からは価值を持たない、と言える.

そこでまず, 各水素エネルギーの評価項目に対し, ガソリンよりも改善される項目を白色で, 悪化する項 目を薄灰色で示す. 次に, 水素エネルギーがサステイ ナビリティを持った自動車用燃料として導入されるた めの絶対条件を「ガソリンよりも温暖化への影響を小 さくでき，また同時に，資源枯渴への影響も低減でき ること」と設定する. そして, 導入にあたっての十分 条件を「経済性つまりコストが妥当な值であること」 と設定する. すると，本研究で想定した水素エネルギ 一の中では, 天然ガス改質による水素エネルギーと, 原子力電解による水素エネルギ一が導入の候補として 挙がる. 一方, 自然エネルギ一を用いた水素エネルギ 一か脚光を浴びているが，これらは温暖化や資源枯渴 に対する影響は低減できるものの, 土地利用や経済性 の観点から導入が難しいと判断される. また, 自然工 ネルギーには資源枯渴はなくとも, 量的（密度的）限 界が存在する. それゆえ, 自然エネルギ一を用いた水 素エネルギーは脇役として有望であるが, 主役にはふ さわしくない. そして, 広大な国土を持つ海外で, 自 然エネルギーを安価に得ることによって経済性を向上 できた場合のみ，補完的な役割での導入が可能になる， と考えられる.

\section{7. 炭秦税㬴入の效果}

現段階において原子力電解による水素エネルギー には経済性がないことから，これが導入の障壁となつ てくる. そこで, 原子力電解による水素エネルギ一の コストをガソリンと競合可能なものとするために, 例として, 炭素税を導入する効果を見積もった.

炭素税は・次エネルギーの炭素含有量に応じて課 税されるものであるから, 水素エネルギーシステムや 石油 (ガソリン) システムの建設, 運用, 保守段階で 消費する全ての化石燃料に対してなされる課税は, 全 て消費者コストに転嫁される。したがって，LOCO2 解析の結果をもとに, 水素エネルギ一およびガソリン に対する炭素税導入の効果を見積もることが出来る.

算出にあたっては，税収の還流等は考えず，また， 簡単化のため, 水素エネルギーシステムおよび石油
（ガソリン）システムに投入される化石燃料は，全て 日本国内から供給されると仗定した.つまり, 原料採 掘のための海外プラントの建設や運用, 日本国内への 燃料輸送など，国外で想定される活動の化石燃料も日 本国内から供給されることとした.

すると, 式（9）のように炭素税額が決定され, 消 費者が負担すべきコストが算出できる. ただし, 式中 の $12 / 44$ は 002 重量を炭素重量に変換するための係 数である.

$$
\begin{aligned}
& P_{\text {Sales }}=P_{L . C}+C_{L . C} \times 12 / 44 \times T_{\text {Carbon }} \\
& \text {... (9) }
\end{aligned}
$$

$P_{\text {Sales }}$ : 消費者が負担すべきコスト原単位（円 $\left./ \mathrm{kJ} \mathrm{J}-\mathrm{H}_{2}\right)$

$P_{L . C}$ : 水素エネルギーシステム全体でのライフサイク ルコスト原単位 (円 $\left./ \mathrm{kJ}-\mathrm{H}_{2}\right)$

$C_{L . C}$ : 水素エネルギーシステム全体でのライフサイク ル $\mathrm{CO} 2$ 原単位 $\left(\mathrm{kg}-\mathrm{CO} 2 \mathrm{~kJ}-\mathrm{H}_{2}\right)$

$T_{\text {Carbon }}:$ 炭素税額 $($ 円 $/ \mathrm{C}$ C $)$

なお, ガソリンの場合についても, 水素エネルギ 一の場合と同様にして算出することが出来る. ただ しガソリンのコスト原単位には、前述したように、 現在かけられているような税金は含まない，そして， この原単位に単位距離走行でのエネルギー消費量 （第4 章参照）を乗じることによって,「自動車 1 $\mathrm{km}$ 走行あたり」に消費者が負担すべきコストが算 出され, 図7のように表せる.

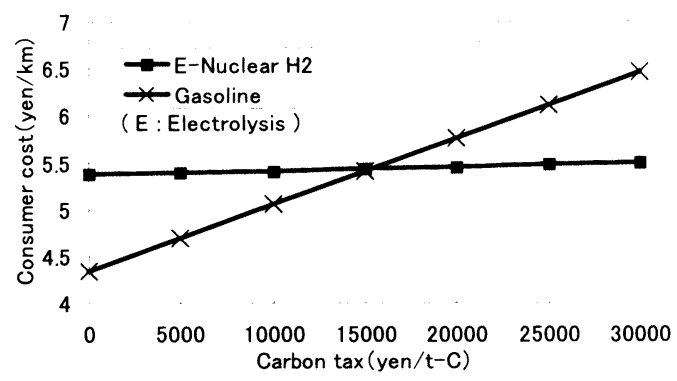

Fig.7 Relation between Carbon tax and Consumer cost

図 7 から，およそ 15000 円/ttC の炭素税によって, 原子力電解による水素エネルギーのコストはガソリ ンと拮抗するようになることがわかる. また, この 課税によって, ガソリンの価格は 11 円/L上昇する ことになる. しかし, 表 2 で示したような現在の 
ガソリンに対して掛けられている税の枠組みを, 環 境性を軸として見直すことによって，この炭䒺税額 は受容性のある課税額になる，と考えられる.

以上から，炭素税を導入することによって原子力 電解による水素エネルギーにも経済性を持たせるこ とが出来, 自動車用燃料としての導入が可能になる, と判断できる.

\section{8. 結}

本稿では，水素エネルギーの生産や利用といった 特定の段階に着目することで生じる期待感に対し, 限定された段階に着目した議論では, 水素エネルギ 一特有の潜在的な環境負荷を見出すことが出来ない と指摘して, 水幸エネルギーシステム全体を対象と した LCA を実施した. そして, LCE, LCCO2, LCCOST, LandUse の側面から水素エネルギーの 自動車用燃料としての導入可能性について検討した 結果, 以下の知見を得た.

（1）自動車用燃料として水素エネルギーを用いる 場合には, 自動車走行時の $\mathrm{CO} 2$ 排出は 0 となる. しかし, 走行に必要なエネルギーを生産し, 輸送し, 供給するといったエネルギーシステムの建設, 運用, 保守も勘案すると, トータルでの $\mathrm{CO} 2$ 排出量が, ガソリンを用いた場合よりも大きくなることがある.

すなわち, 水素エネルギーならばクリーンである, といった考え方は, 水素エネルギーの利用段階だけ に着目した認識で，水素エネルギーが潜在的に有す る環境負荷は、そのライフサイクル全体に着目する ことで明らかになる.

（2）サステイナビリティの観点から, 天然ガス改 質による水素エネルギーと原子力電解による水素エ ネルギーは, 自動車用燃料としての導入が期待でき る. ただし, 原子力電解による水素エネルギ一に経 済性を持たせるためには 15000 円/t-C 以上の炭素課 税が必要である. ·方, 自然エネルギ一を用いた水 素エネルギーは，広大な国土を持つ海外で，自然工 ネルギーを安価に得ることによって経済性を向上で きた場合のみ, 補完的な役割での導入が可能になる。

\section{文献}

[1] 内山洋司ら, 電力中央研究所報告一発電プラント のエネルギー収支分析，（1991）。
[2] NEDO, 平成 10 年度成果報告書一水素利用国 際クリーンエネルギーシステム技術（WENET）サブタスク 3 全体システム概念設計, (1999).

[3]（社）資源協会，大都市生活のライフサイクル エネルギー，（1999）。

[4] NEDO, 平成 6 年度 成果報告書一水素利用国際 クリーンエネルギーシステム技術（WE-NET） サブタスク 3 全体システム概念設計，（1995）.

[5] NEDO, 平成 9 年度成果報告書一水素利用国際 クリーンエネルギーシステム技術 (WE-NET) サブタスク 3 全体システム概念設計，（1998）.

[6] 平岡克英ら, 運輸交通機関の水素エネルギーシ ステム化による省石油と $\mathrm{CO} 2$ 低減, 船舶技術研 究所報告, $27-3$ (1990)，301-329.

[7] 資源エネルギー庁, 総合エネルギー調査会第 70 回原子力部会資料，（2000）。

[8] 経済産業省, 総合資源エネルギ一調査会 新エネ ルギー部会報告書一今後の新エネルギー対策の あり方について，（2001）。

[9]（財）日本エネルギ一経済研究所 H.P, http://eneken.ieej.or.jp/

[10] 第·商品株式会社. H.P, http://www.dai-ichi.co.jp/

[11]関西電力，プレスリリースー新鳩谷水力発電所 の建設申し入れ及び新鳩谷水力発電所に関する 環境影響調査書ならびに環境影響評価準備書の 提出について，（1998）.

[12] 内山洋司, 発電技術のエネルギ一密度と供給信 頼性，エネルギー・資源，18－2（1997）， $88-90$.

[13] 東京電力, プレスリリースー富津火力発電所 3 号系列の営業開始について，（2001）.

[14] NEDO, 平成 9 年度成果報告書一水素利用国 際クリーンエネルギーシステム技術（WENET) サブタスク 4 水素製造技術の開発, (1999).

[15] エクソンモービル社 H.P, http://www.prod.exxonmobil.com/

[16] 小林紀，エネルギ一資源とライフサイクルアセ スメント，自動車技術，56-7（2002）, 27 - 31.

[17] 小林紀ら, 各種自動車の効率および $\mathrm{CO} 2$ 排出 の検討, 自動車技術会学術講演会前刷集 996,

(1996) , 237 - 240. 